\title{
ANALISIS PRODUKTIVITAS SEBAGAI SALAH SATU INDIKATOR KESEHATAN HUTAN \\ (Studi Kasus Pada Hutan Rakyat Jati di Kecamatan Natar Kabupaten Lampung Selatan Provinsi Lampung)
}

\author{
ANALYSIS OF PRODUCTIVITY AS AN INDICATOR OF FOREST HEALTH \\ (Case Study in Jati Community Forest, Natar District, South Lampung Regency, Lampung \\ Province) \\ Oleh
}

Siti Fauzia Rochmah ${ }^{1)}$, Rahmat Safe'i ${ }^{2)}$, Afif Bintoro ${ }^{3)}$, Hari Kaskoyo ${ }^{4)}$

1)Mahasiswa Jurusan Kehutanan Fakultas Pertanian Universitas Lampung

2,3,4)Staf Dosen Jurusan Kehutanan Fakultas Pertanian Universitas Lampung

Jl. Prof. Dr. Ir. Sumantri Brojonegoro, Gedung Meneng, Bandar Lampung 35145

Email : rahmat.safe'i@fp.unila.ac.id

Diterima : 20 Agustus 2020 $\quad$ Disetujui: 17 Septemberr 2020

\begin{abstract}
Abstrak
Saat ini, hutan rakyat semakin menunjukkan peranan penting dalam memenuhi kebutuhan kayu bagi industri perkayuan. Hal tersebut terlihat dari produksi kayu bulat yang terus menurun setiap tahunnya. Berkurangnya pasokan kayu dari hutan alam dan hutan tanaman menjadi salah satu alasan mengapa hutan rakyat dijadikan sebagai alternatif bagi pemenuhan kebutuhan bahan baku kayu industri. Penelitian ini bertujuan untuk mengetahui nilai parameter indikator produktivitas dan status kesehatan hutan rakyat jati di Kecamatan Natar. Untuk mencapai hal tersebut, tahapan-tahapannya antara lain: penentuan jumlah kalster plot, pembuatan klaster plot FHM di hutan rakyat jati, pengumpulan data dan analisis data produktivitas dan nilai akhir kesehata hutan. Hasil dari penelitian ini menunjukkan hutan rakyat jati di Kecamatan Natar Kabupaten Lampung Selatan memiliki nilai kesehatan hutan yang baik berdasarkan indikator produktivitas. Hal tersebut berpengaruh terhadap pengelolaan hutan rakyat kedepannya dengan fungsi utama hutan yaitu produksi. Dengan diketahuinya nilai produktivitas dan kondisi kesehatan hutan, maka pengelola dapat membuat keputusan pengelolaan hutan yang tepat.
\end{abstract}

Kata kunci : hutan rakyat, indikator produktivitas, LBDs, kesehatan hutan.

\begin{abstract}
.
Currently, community forests are increasingly showing an important role in meeting the timber demand for the timber industry. This can be seen from the log production which continues to decline every year. The reduced supply of wood from natural and plantation forests is one of the reasons why community forests are used as an alternative to meet the demand for industrial wood raw materials. This study aims to determine the parameter value of productivity indicators and health status of jati community forests in Natar District. To achieve this, the stages include: determining the number of plot calculators, making FHM plot clusters in teak community forests, collecting data and analyzing productivity data and the final forest health value. The results of this study indicate that jati community forests in Natar District, South Lampung Regency have good forest health values based on productivity indicators. This will affect the management of community forests in the future with the main function of forests, namely production. By knowing the productivity value and health condition of the forest, managers can make appropriate forest management decisions.
\end{abstract}

Keywords: community forest, productivity indicators, LBDs, forest health.

DOI: $10.30598 /$ jhppk.2020.4.2.204

ISSN ONLINE: 2621-8798

Page 204 


\section{PENDAHULUAN}

Hutan rakyat adalah hutan buatan melalui penanaman tanaman tahunan (tanaman keras) di lahan milik, baik secara perorangan, marga maupun kelompok (Anwar, 2018). Tujuan dari penanaman tersebut di antaranya untuk meningkatkan produktivitas lahan kritis atau areal yang tidak produktif secara optimal dan lestari serta membantu masyarakat dalam penyediaan kayu bangunan, bahan baku industri dan kayu bakar (Ethika dkk., 2014).

Saat ini, hutan rakyat semakin menunjukkan peranan penting dalam memenuhi kebutuhan kayu bagi industri perkayuan (Sudrajat dkk., 2016). Hal tersebut terlihat dari produksi kayu bulat yang terus menurun setiap tahunnya. Sebagai gambaran, pada tahun 2015 produksi kayu bulat dari hutan alam sebesar $5.624 .053 \mathrm{~m}^{3}$ dan pada tahun 2016 turun menjadi $5.429 .543 \mathrm{~m}^{3}$. Artinya terjadi penurunan produksi sebesar 3,5\% (KLHK, 2017 dalam Midi dkk., 2015). Berkurangnya pasokan kayu dari hutan alam dan hutan tanaman menjadi salah satu alasan mengapa hutan rakyat dijadikan sebagai alternatif bagi pemenuhan kebutuhan bahan baku kayu (Safe'i, 2017). Kurangnya pasokan kayu tersebut dapat diatasi apabila semua hutan rakyat di Indonesia ditanami tanaman berkayu dan produknya adalah kayu.

Salah satu tanaman yang sangat diminati dalam industri perkayuan adalah tanaman jati (Tectona grandis), karena kualitasnya sangat tinggi (Martinah dkk., 2015). Salah satu hutan rakyat yang ada di Provinsi Lampung dengan tanaman pokok jati yaitu di Kecamatan Natar, Kabupaten Lampung Selatan dengan luas 60 Ha. Hutan rakyat jati di daerah tersebut memiliki produktivitas yang sangat tinggi apabila dilihat dari pertumbuhan diameter dan tinggi pohonnya. Sehingga perlu untuk diketahui nilai produktivitasnya.
Alasan utama hutan rakyat jati di Kecamatan Natar memiliki produktivitas yang tinggi yaitu karena bibit yang diperoleh berasal dari permudaan vegetatif berupa stek pucuk. Bibit tersebut diperoleh dari kebun benih atau hutan klon di Jawa Tengah (Perhutani). Dengan demikian, bibit yang diperoleh dari Perhutani akan memiliki potensi variasi genetik total untuk meningkatkan produksi, karena kinerja genotipe yang baik dari induknya akan dapat diulangi secara konsisten pada keturunannya yang dapat membantu produktivitas tanaman jati (Adinugraha dkk., 2014).

Produktivitas merupakan laju pertumbuhan dari suatu pohon atau tegakan dalam periode waktu tertentu atau saat ini. Produktivitas dapat diketahui dengan melakukan pengukuran pertumbuhan pohon (Safe'i dkk., 2019). Pertumbuhan pohon dihitung sebagai luas bidang dasar (LBDs) (Safe'I dan Tsani, 2017). LBDs menggambarkan tingkat pertumbuhan sesaat atau produktivitas pohon dari waktu ke waktu. Sumber data untuk menghitung LBDs yaitu dengan mengukur diameter pohon (Kuswandi, 2017).

Tinggi rendahnya tingkat produktivitas hutan rakyat jati menunjukkan tingkat keberhasilan pengelolaan hutan rakyat. Pernyataan tersebut didukung oleh Supriyanto dkk. (2001) yang menyatakan bahwa produktivitas merupakan salah satu indikator dalam kesehatan hutan sebagai bagian dari tujuan pengelolaan hutan. Sehatnya hutan rakyat jati akan berdampak baik terhadap pemenuhan fungsi utama hutan rakyat jati sebagai hutan produksi. Pemantauan kesehatan hutan merupakan sistem untuk memantau kondisi ekosistem hutan dengan menggunakan metode Forest Health Monitoring (FHM) (Safe'i dkk., 2019). 
Selain itu, kesehatan hutan dapat dijadikan sebagai bentuk pengendalian untuk menjalankan fungsi utama hutan (Safe'i dkk., 2016) dan juga menciptakan kelestarian hutan rakyat jati (Pratiwi dkk., 2018). Oleh karena itu, penelitian ini penting dilakukan untuk mengetahui produktivitas hutan rakyat jati di Provinsi Lampung sebagai salah satu indikator penilaian kesehatan hutan.

\section{METODE PENELITIAN}

Penelitian ini dilakukan pada bulan Juli 2020. Lokasi penelitian dilakukan pada hutan rakyat jati Desa Rulung Helok, Kecamatan Natar,
Kabupaten Lampung Selatan. Peta lokasi penelitian dapat dilihat pada Gambar 1.

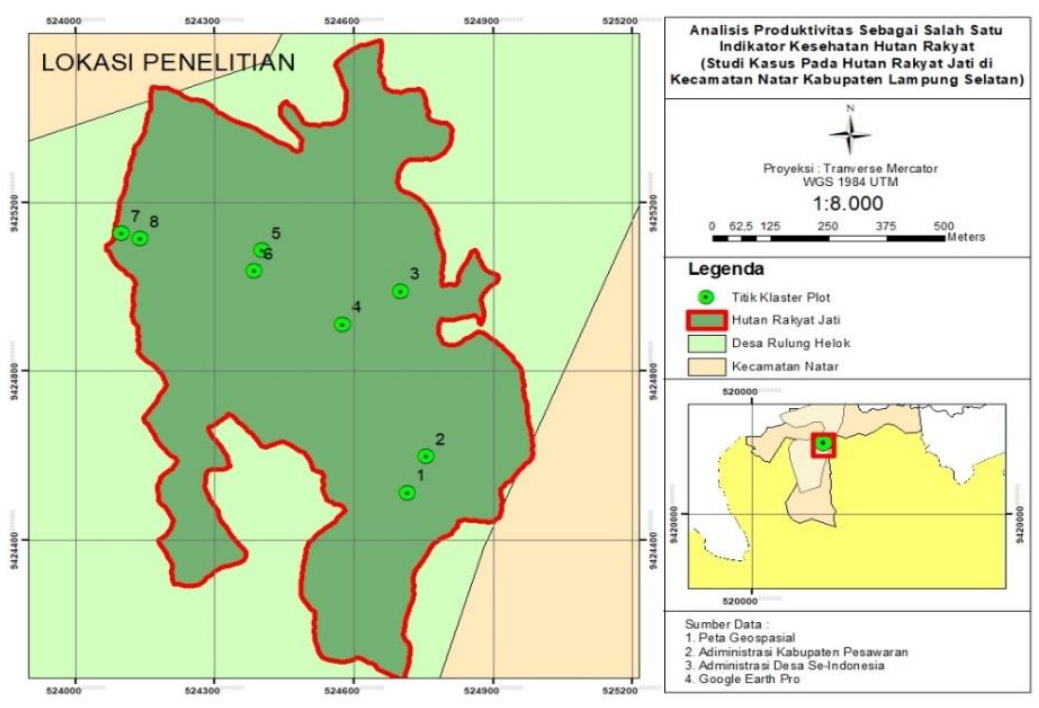

Gambar 1. Peta lokasi penelitian

Alat yang digunakan dalam penelitian terdiri dari: tally sheet, label plastik, paku pines, kompas, spidol permanen, meteran, pita meter $(150 \mathrm{~cm})$, Global Positioning System (GPS), hagameter, dan kamera digital. Objek dalam penelitian ini adalah delapan klaster plot Forest Health Monitoring (FHM) yang berisi tegakan jati pada fase semai, pancang, tiang dan pohon. Pemantauan kesehatan hutan dilakukan dengan metode Forest Health Monitoring (FHM) (Safe'i, 2015). Forest Health Monitoring (FHM) adalah metode pemantauan kondisi kesehatan hutan yang diintroduksikan oleh USDA untuk memonitor yang dirancang untuk kesehatan hutan (Pratiwi dan Safe'i, 2018). Jumlah klaster plot yang dibuat yaitu 8 klaster plot atau 32 plot dengan luas total klaster plot pengamatan adalah 3,2 ha. Penentuan jumlah klaster plot dilaukan dengan metode purposive sampling. Purposive sampling merupakan teknik pengambilan sampel dengan menggunakan pertimbangan tertentu (Sugiyono, 2010). Pertimbangan yang dipakai yaitu tahun tanam dan jarak tanam. Tahun tanam di hutan rakyat jati 
ini antara lain tahun 2006, 2008, 2009, dan 2011. Masing-masing dari tahun tanam tersebut antara lain 2,5x 2,5 $\mathrm{m}$ dan $4 \times 4 \mathrm{~m}$. Sehingga klaster plot yang harus dibuat sebanyak 8 klaster plot.

Desain klaster plot FHM kesehatan hutan dalam hutan rakyat jati dapat dilihat pada Gambar 2. Pemantauan kesehatan hutan dilakukan terhadap indikator ekologis yaitu produktivitas. Beberapa kriteria dalam pembuatan klaster plot FHM, yaitu:

1) Mempunyai annular plot berupa lingkaran dengan jari-jari 17,95 m, subplot dengan jari-jari 7,32 $\mathrm{m}$ dan mikroplot dengan jari-jari 2,07 m.
2) Titik pusat subplot 1 (satu) merupakan titik pusat bagi keseluruhan plot, titik pusat subplot 2 (dua) terletak pada arah $0^{\circ}$ atau $360^{\circ}$ dari titik pusat subplot 1 (satu), titik pusat subplot 3 (tiga) terletak pada arah $120^{\circ}$ dari titik pusat subplot 1 (satu) dan titik pusat subplot 4 (empat) terletak pada arah $240^{\circ}$ dari titik pusat subplot 1 (satu), dengan masing-masing jarak antara titik pusat subplot adalah $36,6 \mathrm{~m}$.

3) Klaster plot terdiri dari 4 annular plot, subplot dan mikroplot serta titik contoh tanah.

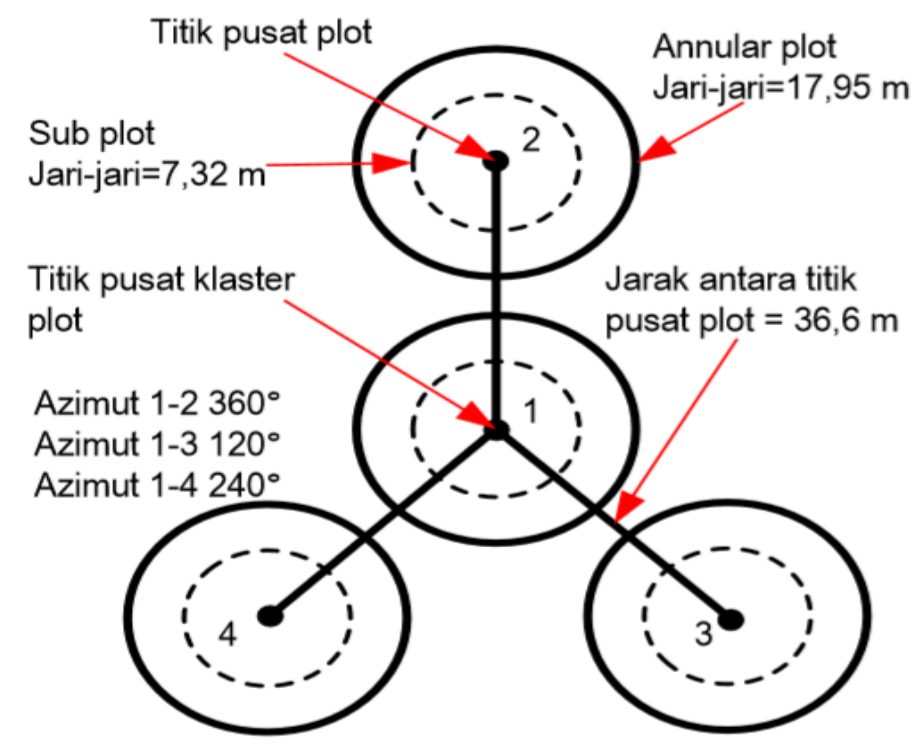

Gambar 2. Desain klaster plot Forest Health Monitoring (FHM)

Pengumpulan data di lapangan diperoleh dengan cara pengukuran parameter indikator produktivitas. Parameter pada fase semai, pancang, tiang dan pohon.

yang digunakan dalam penelitian ini adalah pertumbuhan pohon (LBDs) yang datanya dapat diperoleh melalui pengukuran diameter. Diameter batang diukur $1,3 \mathrm{~m}$ di atas permukaan tanah. Teknik pengukuran pertumbuhan pohon atau produktivitas dilakukan terhadap tanaman jati yang berada di dalam setiap plot klaster. Pengukuran tersebut dilakukan
Pertumbuhan pohon adalah pertambahan dari jumlah dan dimensi pohon, baik diameter maupun tinggi yang terdapat pada suatu tegakan (Davis and Jhonson 1987 dalam Safe'i dan Tsani., 2016). Pertumbuhan pohon dihitung sebagai pertumbuhan luas bidang dasar (LBDs). Parameter LBDs dipilih karena merupakan parameter yang mudah dalam 
pengukurannya dan memiliki tingkat pertumbuhan luas bidang dasar (LBDs) konsistensi yang tinggi. Maka dari itu, pohon (Cline 1995). Berikut merupakan pertumbuhan diameter pohon dapat rumus dari LBDs:

digunakan sebagai dasar perhitungan

$$
\text { LBDs }=1 / 4 \times \pi \times d^{2}
$$

Keterangan :

$\begin{array}{ll}\text { LBDs } & =\text { luas bidang dasar individu pohon }\left(\mathrm{m}^{2}\right) \\ \mathrm{d} & =\text { diameter batang }(1,3 \text { meter dari dasar pohon }) \\ \pi & =\text { konstansa }(3,14)\end{array}$

Penilaian kesehatan hutan pada hutan rakyat jati di Kecamatan Natar diperoleh dari nilai akhir kondisi kesehatan hutan jati tersebut. Penilaian ini bertujuan untuk menetukan kondisi kesehatan hutan saat ini berdasarkan indikator dari produktivitas. Untuk mendapatkan nilai akhir kesehatan hutan dapat menggunakan rumus sebagai berikut :

$$
\mathrm{NKH}=\mathrm{NT} \times \mathrm{NS}
$$

Keterangan :

$\begin{array}{ll}\text { NKH } & =\text { nilai akhir kondisi kesehatan hutan } \\ \text { NT } & =\text { nilai tertimbang parameter dari indikator produktivitas } \\ \text { NS } & =\text { nilai skor parameter dari indikator produktivitas }\end{array}$

Di mana, NKH adalah nilai akhir kondisi kesehatan hutan, NT adalah nilai tertimbang parameter dari masing-masing indikator kesehatan hutan, NS adalah nilai skor parameter dari masing-masing indikator kesehatan hutan (Safe'i dkk., 2018). Nilai skor diperoleh dari transformasi terhadap nilai parameter masing-masing klaster plot dengan rentang nilai skor 1-10. Sedangkan nilai tertimbang (NT) diperoleh dengan

\section{HASIL DAN PEMBAHASAN}

Hutan rakyat jati di Kecamatan Natar Kabupaten Lampung Selatan bertujuan untuk pengembangan tanaman berkayu untuk bahan baku industri di Pulau Jawa tepatnya di Jawa Timur. Salah satu manfaat hutan rakyat yang dapat dirasakan oleh masyarakat secara langsung yaitu meningkatkan produktivitas lahan, sumber pendapatan dan bahan baku industri (Safe'i dkk., menggunakan Analytic Networking Process (ANP) (Safe'i dkk., 2016). Karena hanya menggunakan satu indikator, ANP tidak digunakan. Nilai NT untuk satu indikator yaitu 1 (satu). Namun, pada penelitian ini tidak menggunakan ANP dalam penentuan nilai tertimbang. Hal tersebut dikarenakan tidak ada indikator lain untuk dilakukannya pembandingan berpasangan.

2017). Hutan rakyat jati tersebut menerapkan pola tanam monokultur tanpa ada seresah di lantai hutannya. Tujuan pengelola memilih pola tersebut yaitu untuk memaksimalkan hasil hutan berupa kuantitas dan kualitas kayu yang baik (Warsiyah, 2013). Sehingga, pengelola fokus terhadap pertumbuhan pohon (diameter dan tinggi).

Faktor yang menentukan kuantitas dan kualitas kayu atau pohon salah satunya yaitu kesehatan hutan. 
Kesehatan hutan rakyat jati menjadi penentu utama dalam pencapaian pengelolaan hutan lestari atau PHL (Safe'i dkk., 2013). Pemantauan kesehatan hutan merupakan kegiatan yang dapat melaporkan dan menilai tentang status kesehatan hutan saat ini dengan menggunakan indikator ekologis yang terukur (Putra, 2004) yaitu produktivitas. Cermin dari tingkat kesehatan dan keberhasilan pengelolaan hutan rakya jati dilihat dari tinggi rendahnya produktivitas dalam hutan tersebut (Putra, 2004). Untuk memenuhi fungsi produksi hutan rakyat tersebut, maka tingkat produktivitas hutan rakyat merupakan hal yang harus diperhatikan (Safe'i, 2017).

Produktivitas merupakan laju pertumbuhan dari suatu pohon atau tegakan dalam periode waktu tertentu.
Tingkat produktivitas pohon jati dapat diketahui dengan melakukan pengukuran pertumbuhan pohon (Safe'i dkk., 2019). Menurut Riyanto dan Pamungkas (2010) pola pertumbuhan diameter dan titik optimum pertumbuhan diameter dapat menggunakan kurva laju pertumbuhan pohon. Pertumbuhan pohon dihitung sebagai luas bidang dasar (LBDs) (Safe'i dkk., 2013). LBDs dapat dihitung dengan diketahui diameter pohon. Pertumbuhan diameter pohon merupakan parameter pertumbuhan pohon yang mudah dalam pengukurannya dan memiliki tingkat konsistensi yang tinggi (Philip, 1994). Pengukuran parameter indikator Kesehatan hutan dilakukan pada klaster plot dalam sub plot. Hasil penilaian LBDs pada masing-masing klaster-plot dapat dilihat pada Table 1.

Tabel 1. Nilai LBDs pada masing-masing klaster Plot

\begin{tabular}{cc} 
Klaster Plot & LBDs $\left(\mathrm{m}^{2}\right)$ \\
\hline 1 & 0,0390 \\
2 & 0,0419 \\
3 & 0,0397 \\
4 & 0,0413 \\
5 & 0,0378 \\
6 & 0,0373 \\
7 & 0,0312 \\
8 & 0,0328 \\
\hline
\end{tabular}

Sumber: Diolah dari data lapangan

Nilai skor parameter pertumbuhan ratarata pohon per hektar pada masingpohon didasarkan pada besaran nilai LBDS masing klaster-plot (Tabel 2).

Tabel 2. Nilai skoring pada parameter LBDs

\begin{tabular}{cccc}
\hline Skor & \multicolumn{3}{c}{ LBDs } \\
\hline 1 & 0,0312 & - & 0,0322 \\
2 & 0,0323 & - & 0,0332 \\
3 & 0,0333 & - & 0,0343 \\
4 & 0,0344 & - & 0,0354 \\
5 & 0,0355 & - & 0,0365 \\
6 & 0,0366 & - & 0,0375 \\
7 & 0,0376 & - & 0,0386 \\
8 & 0,0387 & - & 0,0397 \\
9 & 0,0398 & - & 0,0407 \\
10 & 0,0408 & - & 0,0419 \\
\hline
\end{tabular}

Sumber: Diolah dari data lapangan 
nilai skoring diberikan pada interval 1-10. Nilai dimulai dari nilai terkecil sampai dengan yang terbesar. Semakin tinggi nilai skor menunjukkan tingkat kesehatan hutan rakyat jati semakin tinggi. Skoring kondisi pertumbuhan pohon didasarkan pada besaran nilai LBDs rata-rata pohon per hektar (Safe'i, 2017). Interval 1-10 tersebut memberikan tingkatan pada setiap nilai yang ada terhadap masingmasing klaster plot ukur yang telah diperoleh sebelumnya.

Nilai ambang batas status kesehatan hutan didasari pada besaran nilai skor parameter LBDs (Tabel 3).

Tabel 3. Nilai ambang batas status kesehatan hutan berdasarkan indikator produktivitas

\begin{tabular}{ccc}
\hline No & Kategori & Kelas Nilai \\
\hline 1 & Baik & $7,00-10,00$ \\
2 & Sedang & $4,00-6,99$ \\
3 & Buruk & $1,00-3,99$ \\
\hline
\end{tabular}

Sumber: Diolah dari data lapangan

Nilai kondisi kesehatan hutan rakyat kategori kondisi sengon pada setiap klaster-plot dengan kesehatan hutan rakyat jati (Tabel 4)

Tabel 4. Nilai akhir status Kesehatan hutan berdasarkan indikator produktivitas

\begin{tabular}{ccc} 
Klaster & NKH & Status \\
\hline 1 & 9 & Baik \\
2 & 10 & Baik \\
3 & 9 & Baik \\
4 & 10 & Baik \\
5 & 7 & Baik \\
6 & 6 & Sedang \\
7 & 1 & Buruk \\
8 & 2 & Buruk \\
\hline
\end{tabular}

Sumber: Diolah dari data lapangan 


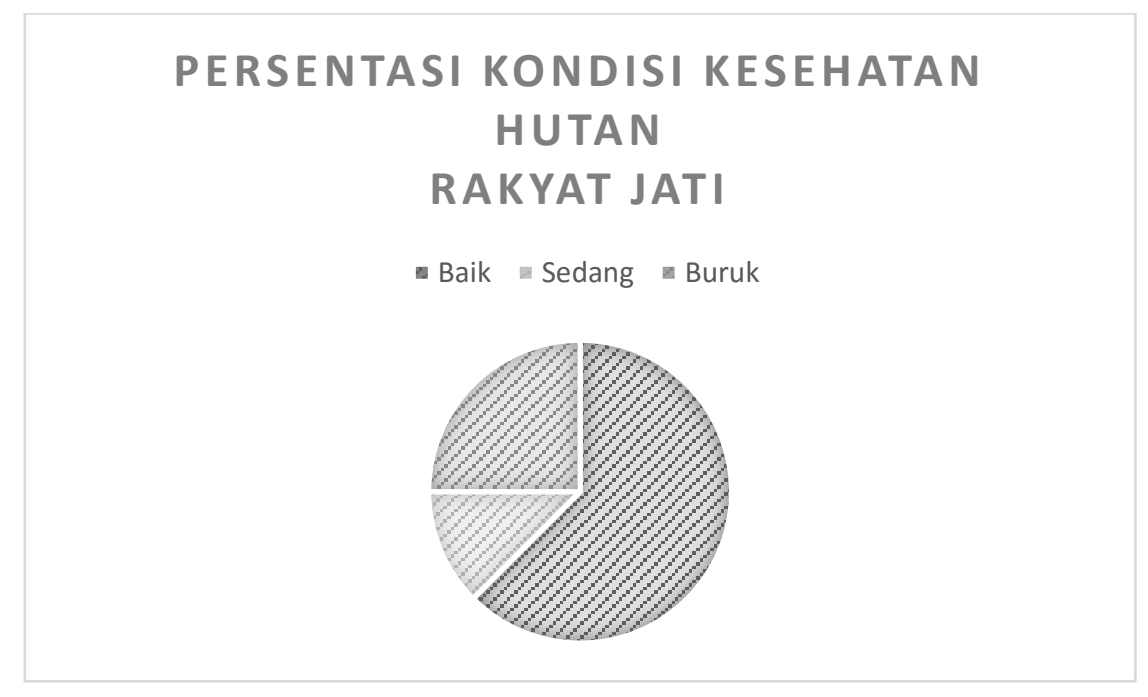

Gambar 3. Persentasi kondisi Kesehatan hutan rakyat jati

Pemilik atau pengelola hutan rakyat jati di Desa Rulung Helok Kecamatan Natar ini memiliki tujuan utamanya menghasilkan kayu untuk di pasarkan ke luar pulau sumatera sebagai kebutuhan bahan baku industri. Bahan baku industri di pulau jawa anatra lain untuk bahan baku bangunan dan perlengkapan rumah tangga. Pemanfaatan hutan rakyat melalui penyediaan bahan baku dalam menopang industri kehutanan menjadi suatu realitas dalam pembangunan kehutanan di Indonesia saat ini (Safe'i, 2017). Hal tersebut membuat kondisi pertumbuhan tegakan jati harus baik. Kondisi tersebut dapat diketahui melalui status kesehatan hutan rakyat jati yaitu dengan mengetahui tingkat produktivitas pohon jati yang berada dalam hutan rakyat tersebut.

Tingkat produktivitas pohon dapat diketahui dengan parameter laju pertumbuhan pohon dengan melakukan pengukuran LBDs (Riyanto, 2009). Luas bidang dasar menggambarkan tingkat pertumbuhan sesaat atau produktivitas pohon dari waktu ke waktu. Sumber data untuk menghitung LBDs yaitu dengan mengukur diameter pohon (Kuswandi, 2017). LBDs merupakan penampang melintang dari diameter setinggi dada $(1,3$ m dari permukaan tanah) (Sahid, 2009). Tingkat produktivitas menjadi salah satu indikator yang sangat penting dan perlu perhatian khusus karena pengelolaan hutan yang berhasil dapat menjadi cermin dari tingkat produktivitas dalam suatu tegakan (Putra, 2004). Apalagi hutan rakyat jati ini memiliki fokus pada peningkatan hasil produksinya berupa diameter dan tinggi pohon. Sehingga perlu adanya pengukuran yang menyatakan kondisi dai hutan rakyat tersebut baik atau tidak.

Produktivitas hutan rakyat jati cenderung mengalami kenaikan seiring dengan bertambahnya umur pohon. Berdasarkan Tabel 1, pertumbuhan tertinggi terdapat pada klaster plot dua dengan nilai $0,0419 \mathrm{~m}^{2}$. Sedangkan pertumbuhan terendah yaitu $0,0312 \mathrm{~m}^{2}$ yang terdapat pada klaster tujuh. Hal tersebut menunjukkan bahwa produktivitas pohon di klaster plot dua tinggi dan di klaster plot tujuh rendah (Safe'i dkk., 2019). Rata-rata dari nilai dari parameter indikator kesehatan hutan 
ini tinggi. Hal ini menunjukkan bahwa semakin bertambahnya umur pohon maka pertumbuhan pohon akan semakin tinggi. Besarnya tingkat pertumbuhan akan berkolerasi terhadap kesehatan hutan rakyat jati. Perbedaan nilai LBDs tersebut dikarenakan tingkat pertumbuhan pohon yaitu tinggi dan diameter pohonnya lebih tinggi, sehingga memicu pertumbuhan yang lebih tinggi begitupun sebaliknya (Ansori dkk., 2020). Dengan begitu, pertumbuhan pohon yang digambarkan dengan LBDs dapat digunakan untuk menjelaskan produktivitas saat ini (Cline, 1995). Indiaktor produktivitas akan menjadi dasar penilaian kesehatan hutan selain indikator keanekaragaman hayati, vitalitas dan kualitas tapak.

Untuk mengetahui nilai status kondisi kesehatan hutan rakyat jati dilakukan dengan melakukan perhitungan nilai akhir kondisi kesehatan hutan rakyat jati. Nilai akhir kondisi kesehatan hutan rakyat jati merupakan hasil dari skoring terhadap nilai LBDs yang diperoleh. Nilai tersebut doperoleh hasil dari pengurangan nilai maksimal terhadap nilai minimal dan kemudian dibagi dengan tiga (kategori yang dipakai). Dari ketiga kategori yang ada maka akan diketahui kondisi kesehatan hutan jati di Kecamatan Natar Kabupaten Lampung Selatan. Delapan klaster plot yang dibuat untuk mewakili luasan hutan rakyat jati akan memiliki kondisi yang berbeda-beda tergantung kepada besarnya diameter dan umur pohon yang diukur.

Berdasarkan Tabel 4, dari delapan klaster plot yang dibuat terdapat lima klaster plot dengan kategori baik, satu klaster plot dengan kategori sedang, dan dua klaster plot untuk kategori buruk. Maka dapat dikatakan kondisi kesehatan hutan rakyat jati di Kecamatan Natar Kabupaten Lampung Selatan dengan kategori baik. Kondisi tersebut disebabkan oleh tingginya nilai LBDs pada masingmasing klaster plot. Seperti yang dinyatakan oleh Safe'i dkk. (2015) bahwa semakin tinggi nilai skor menunjukkan bahwa tingkat kesehatan hutan semakin tinggi, sebaliknya semakin rendah nilai skor maka tingkat kesehatan hutan akan semakin rendah. Tingginya nilai Kesehatan hutan di hutan rakyat jati disebabkan salah satunya oleh bibit jati yang diperoleh memiliki genetik unggul. Alasan lain karena tempat tumbuh serta syarat tumbuh lainnya memenuhi untuk ditanami oleh jati (Tectona grandis).

Dari hasil analisis terhadap delapan klaster plot, perlu dilakukan perlakuan intensif terhadap klaster yang masuk dalam kategori sedang dan buruk. Perlakuan tersebut disebut dengan pemeliharaan yang merupakan kegiatan yang dilakukan pengelola hutan rakyat untuk memelihara tanaman miliknya sehingga tanaman tersebut dapat tumbuh dengan baik dan memberikan hasil yang maksimal (Simon, 2004). Adapun perlakukan yang dapat dilakukan seperti penjarangan, pendangiran, penyiangan gulma pengendalian hama penyakit dan pemangkasan terhadap cabang-cabang yang dapat menyebabkan perlambatan pertumbuhan tanaman jati. Namun, di hutan rakyat jati tersebut kegiatan pemeliharaan yang sering dilakukan yaitu penjarangan. Tujuan dari penjarangan yaitu agar tanaman memiliki ruang tumbuh yang cukup untuk pertumbuhan yang normal, sehingga akan diperoleh ukuran tanaman yang besar (Hapsari dkk., 2017). Penjarangan dilakukan pada tanaman yang menghasilkan kayu agar tanaman mendapatkan tinggi bebas cabang yang sempurna dan meningkatkan hasil panen kayu (Oktaviyani dkk., 2017). Hasil dari penjarangan tersebut akan membuat diameter batang membesar 
sehingga nilai parameter indikator kesehatan hutan meningkat.

Klaster plot dengan kondisi kesehatan hutan yang baik pun tidak lepas dari pemeliharaan. Untuk klaster plot dengan kondisi kesehatan yang baik harus diperhatikan cara pemanenannya agar tetap memperhatikan aspek kelestarian. Segala bentuk pengelolaan harus berdasarkan prinsip keberlanjutan dari fungsi hutan. Prinsip tersebut akan memberi dampak yang baik terhadap kesehatan hutan khususnya ditinjau dari produktivitas tanamannya. Dalam hal ini, indikator produktivitas dalam kesehatan hutan sangat penting mengingat hutan rakyat memiliki fungsi produksi.

Kesehatan hutan rakyat yang baik akan berdampak pada pertumbuhan pohon

\section{KESIMPULAN}

Hasil penelitian menunjukkan bahwa nilai indikator produktivitas melalui parameter LBDs pada masingmasing klaster plot adalah 0,0390; 0,$0419 ; 0,0397 ; 0,0413 ; 0,0378 ; 0,0373$; 0,0312 ; dan 0,0328 . Tingkat produktivitas di hutan rakyat jat tersebut tergolong tinggi. Sedangkan nilai status kondisi kesehatan hutan rakyat jati di Desa Rulung Helok Kecamatan Natar Kabupaten Lampung Selatan adalah berada pada kondisi kesehatan hutan yang baik (klaster plot 1, 2, 3, 4, dan 5), sedang

\section{DAFTAR PUSTAKA}

Adinugraha, H. A. dan Mahfudz. 2014. Pengembangan Teknik Perbanyakan Vegetatif Tanaman Jati Pada Hutan Rakyat, Jurnal WASIAN; 1(1) : 3944.

Ansori, D.P., Safe'i, R. dan Kaskoyo, H. 2020. Penilaian Indikator Kesehatan Hutan Rakyat Pada Beberapa Pola Tanam (Studi Kasus di Desa Buana Sakti, Kecamatan Batang Hari, Kabupaten Lampung Timur), Perennial; 16(1): 1-6. selanjutnya. Baiknya kondisi kesehatan hutan juga akan memberikan kontribusi terhadap tujuan pengelolaan hutan rakyat jati yaitu produksi. Dengan sehatnya hutan rakyat jati, maka pengelola hutan rakyat akan mendapatkan keuntungan yang besar dari setiap penjualan kayu jatinya karena produktivitasnya yang tinggi. Permintaan pasokan kayu tersebut tidak lepas dari kualitas kayu yang dihasilkan oleh hutan rakyat. Menurut Apriyanto dkk.(2016) hutan rakyat tidak lagi hanya sebagai "sambilan", tetapi dituntut dengan produktivitas tinggi dan tetap lestari. Kelestarian tersebut dapat diimplementasikan dengan melakukan pemantauan kesehatan hutan secara berkelanjutan atau secara berkala.

(klaster plot 6) dan buruk (klaster plot 7 dan 8). Nilai status kondisi kesehatan hutan ini penting dalam pengelolaan hutan rakyat terutama untuk mengambil keputusan yang tepat berdasarkan indikator produktivitas dengan parameter pengukuran luas bidang dasar (LBDs) yang dapat menyebabkan melambatnya laju pertumbuhan pohon jati. Dengan demikian, status kondisi hutan rakyat jati di Desa Rulung Helok Kecamatan Natar Kabupaten Lampung Selatan rata-rata berada pada kondisi yang baik.

Anwar. 2018. Potensi Dan Prospek Pengembangan Hutan Rakyat Di Kabupaten Parigi Moutong Sulawesi Tengah, Jurnal Warta Rimba; 6(1) : 93-101.

Apriyanto, D.,Hardjanto dan Hero, Y. 2016. Peningkatan Peran Hutan Rakyat Dalam Mendukung Ketahanan Pangan Dan Penanggulangan Kemiskinan (Studi Kasus Di Kecamatan Nanggung, Kabupaten Bogor), Jurnal Silvikultur Tropika; 7(3) : 165-173. 
Cline, S.P. 1995. FHM: Environmental Monitoring and Assesment Program Washington D.C. (US): U.S Environmental Protection Agency, Office of Research and Development.

Ethika, D., Puwanto, R. H., Senawi dan Masyhuri. 2014. Peranan Petani Terhadap Strategi Pembangunan Hutan Rakyat Di Bagian Hulu Sub Das Logawa Di Kabupaten Banyumas, Jawa Tengah, $J$. Manusia dan Lingkungan; 21 (3) : 377-385.

Hapsari, R., Indradewa, D. dan Ambarwati, E. 2017. Pengaruh Pengurangan Jumlah Cabang Dan Jumlah Buah Terhadap Pertumbuhan Dan Hasil Tomat (Solanum lycopersicum L.), Vegetalika; 6(3) : 37-49.

Kuswandi, R. 2017. Model pertumbuhan tegakan hutan alam bekas tebangan dengan sistem tebang pilih di papua, Jurnal Pemuliaan Tanaman Hutan; 11(1) : 45-55.

Martinah, V., Marjena, Ruchaemi, A. dan Ruhiyat, D. 2015. Pertumbuhan Hutan Tanaman Jati (Tectona Grandis Linn.F.) Di Kalimantan Timur, Jurnal Agrifor; 14(2) : 287292.

Midi, L. O dan Mando, L. O. A. S. 2015. Penaksiran Potensi Kayu Dari Hutan Rakyat Di Kecamatan Barangka Kabupaten Muna, Ecogreen; 1(1) : 89-100.

Oktaviyani, E.S., Indriyanto dan Surnayanti. 2017. Identifikasi Jenis Tanaman Hutan Rakyat Dan Pemeliharaannya Di Hutan Rakyat Desa Kelungu Kecamatan Kotaagung Kabupaten Tanggamus, Jurnal Sylva Lestari; 5(2) :63-77.

Philip MS. 1994. Measuring Trees and Forest. Wallingford: CAB Int.

Pratiwi, L. dan Safe'i, R. 2018. Penilaian Vitalitas Pohon Jati Dengan Forest
Health Monitoring Di Kph Balapulang, Ecogreen; 4(1) : 9-15.

Putra, E. I. 2004. Pengembangan Metode Penilaian Kesehatan Hutan Alam Produksi. Tesis. Institut Pertanian Bogor, Bogor, P.63.

Riyanto, H. D. 2009. Penjarangan Selektik Dalam Upaya Peningkatan Riap Diameter Hutan Rakyat Sengon, Jurnal Tekno Tanaman; 2(3): 115120.

Riyanto HD dan Pamungkas BP. 2010. Model Pertumbuhan Tegakan Hutan Tanaman Sengon Untuk Pengelolaan Hutan, J Tekno Hutan Tanaman; 3(3):113-120.

Safe'i, R. Hardjanto, Supriyanto dan Sundawati, L. 2013. Pengembangan Metode Penilaian Kesehatan Hutan Rakyat Sengon (Falcataria Moluccana (Miq.) Barneby \& J.W. Grimes), Jurnal Penelitian Hutan Tanaman; 12(3) : 175-187.

Safe'i, R. 2015. Kajian Kesehatan hutan dalam Pengelolaan Hutan Rakyat di Provinsi Lampung. disertasi. Institut Pertanian Bogor, Bogor, p.101.

Safe'i, R. 2017. Pengembangan Metode Penilaian Kesehatan Hutan Rakyat Sengon (Paraserianthes falcataria). Makalah diberikan pada Seminar Doktor Fakultas Pertanian UNILA. 9 Maret. Bandar Lampung.

Safe'i, R. dan Tsani, M. K. 2016. Kesehatan Hutan: Penilaian Kesehatan Hutan Menggunakan Teknik Forest Health Monitoring. Buku. Lembaga Penelitian Dan Pengabdian Kepada Masyarakat Universitas Lampung, Bandar Lampung, P.102.

Safe'i, R., dan Tsani, K. M. 2017. Penyuluhan Program Kesehatan Hutan Rakyat Di Desa Tanjung Kerta Kecamatan Kedondong Kabupaten Pesawaran, Jurnal Pengabdian kepada Masyarakat; 1(1): 1-3. 
Safei'i, R., Erly, H., Wulandari, C. dan Kaskoyo, H. 2018. Analisis Keanekaragaman Jenis Pohon Sebagai Salah Satu Indikator Kesehatan Hutan Konservasi, Jurnal Perennial; 14(2): 32-36.

Safe'i, R., Wulandari, C. dan Kaskoyo, H. 2019. Analisis Kesehatan Hutan Dalam Pengelolaan Hutan Rakyat Pola Tanam Agroforestri di Wilayah Kabupaten Lampung Timur, ANR Conserence Series 02, Talenta Publisher, Universitas Sumatera Utara. pp.97-103.

Safe'i, R., Wulandari, C. dan Kaskoyo, H. 2019. Penilaian Kesehatan Hutan Pada Berbagai Tipe Hutan Di Provinsi Lampung, Jurnal Sylva Lestari; 7(1) : 95-109.

Sahid. 2009. Penafsiran Luas Bidang Dasar Tegakan Pinus Merkusii Menggunakan Foto Udara Di Kesatuan Pemangkuan Hutan (Kph) Kedu Perum Perhutani Unit 1 Jawa Tengah, Forum Geografi; 23(2) : 112-122.

Simon. 2004. Aspek Sosio-Teknis Pengelolaan Hutan Jati di Jawa. Buku. Pustaka Belajar, Yogyakarta.

Sudrajat, A., Hardjanto dan Sundawati, L. 2016. Partisipasi Petani Dalam Pengelolaan Hutan Rakyat Lestari: Kasus Di Desa Cikeusal Dan Desa Kananga Kabupaten Kuningan, Jurnal Silvikultur Tropika; 7(1) : 817.

Sugiyono. 2010. Metode Penelitian Pendidikan Pendekatan Kuantitatif, Kualitatif, Dan $R \& D$. Buku. Alfabeta, Bandung.

Supriyanto, Stolte KW., Soekotjo dan Gintings, AN. 2001. Present Status of Crown Indicators. Di dalam: Forest Health Monitoring to Monitor The Sustainability of Indonesian Tropical Rain Forest. Volume 1. Japan: ITTO dan Bogor, SEAMEO-BIOTROP, p.124.
USDA. 1999. Forest Health Monitoring Field Methods Guide International. Buku. National Forest Health Program, Washington DC, p.230.

Warsiyah. 2013. Pola Tanam Masyarakat Di Sekitar Hutan Bunder Gunung Kidul, Jurnal Rekayasa Lingkungan; 13(2) : 16-30. 